\title{
Produktivitas Kerja Perawat Ruang Rawat Inap
}

\author{
Chandra Tri Wahyudi ${ }^{1}$, Catur Septiawan G $^{2}$ \\ ${ }^{1}$ Universitas Pembangunan Nasional "Veteran" Jakarta \\ ${ }^{2}$ Sekolah Tinggi Ilmu Kesehatan Indonesia Maju \\ Email: ${ }^{1}$ chan.tw.1987@ gmail.com, ${ }^{2}$ uima.penjaminmutu@ gmail.com
}

\begin{abstract}
Abstrak
Penelitian ini bertujuan menganalisis pengaruh langsung dan tidak langsung serta besarannya motivasi kerja, beban kerja dan kepemimpinan kepala ruangan terhadap produktivitas kerja perawat ruang rawat inap di RS Bhineka Bhakti Husada (BBH) Tangerang Selatan 2014. Penelitian ini berfokus pada faktor-faktor yang mempengaruhi produktivitas kerja perawat di ruang rawat inap di rumah sakit. Metode penelitian ini menggunakan desain cross sectional pada 80 orang perawat ruang rawat inap RS BBH yang diperoleh dengan tehnik total sampling. Hasil uji koefisien parameter antara beban kerja terhadap produktivitas kerja menunjukkan terdapat pengaruh langsung sebesar $15,57 \%$, sedangkan untuk pengaruh tidak langsung sebesar $2,17 \%$. Hasil lainnya antara motivasi terhadap produktivitas kerja menunjukkan terdapat pengaruh langsung sebesar $26,77 \%$. Hasil uji koefisien parameter antara kepemimpinan terhadap produktivitas kerja menunjukkan terdapat pengaruh langsung sebesar $27,90 \%$, sedangkan untuk pengaruh tidak langsung sebesar $8,22 \%$. Kesimpulan dalam penelitian ini bahwa variabel produktivitas dipengaruhi oleh beban kerja, kepemimpinan, dan motivasi secara stimultan sebesar $80,63 \%$.
\end{abstract}

Kata Kunci : Beban, Motivasi, Kepemimpinan Kepala Ruangan, Produktivitas

\begin{abstract}
This study aims to analyze the direct and indirect effects and the magnitude of work motivation, workload and leadership of the head of the room on the work productivity of inpatient nurses at the 2014 South Tangerang Bhineka Bhakti Husada (BBH) Hospital. This study focuses on factors that affect work productivity nurse in the inpatient room at the hospital. This research method used a cross sectional design on 80 nurses in the inpatient ward of BBH Hospital which were obtained by total sampling technique. The results of the parameter coefficient test between workload and work productivity show that there is a direct effect of 15.57\%, while for indirect effects is $2.17 \%$. Other results between motivation and work productivity indicate that there is a direct effect of $26.77 \%$. The result of the parameter coefficient test between leadership and work productivity shows that there is a direct effect of $27.90 \%$, while for the indirect effect is $8.22 \%$. The conclusion in this study is that productivity variables are influenced by workload, leadership, and motivation simultaneously by $80.63 \%$.
\end{abstract}

Keywords

: Load, Motivation, Room Leadership, Productivity 


\section{Pendahuluan}

Rumah Sakit merupakan institusi pelayanan kesehatan yang menyelenggarakan pelayanan kesehatan perorangan secara paripurna yang menyediakan pelayanan rawat inap, rawat jalan, dan gawat darurat. ${ }^{1}$ Rumah Sakit yang berada di Indonesia baik yang berkategorik Rumah Sakit Publik maupun yang berkategorik Privat. Pelayanan keperawatan merupakan suatu bentuk pelayanan professional yang merupakan bagian integral dari pelayanan kesehatan yang didasarkan pada ilmu dan kiat perawat. Keperawatan ditujukan kepada individu, keluarga, kelompok atau masyarakat, baik sehat maupun sakit. Praktik keperawatan adalah pelayanan yang diselenggarakan oleh perawat dalam bentuk asuhan keperawatan. ${ }^{2}$

Kontribusi pelayanan keperawatan sangat penting terhadap peningkatan mutu pelayanan kesehatan dan salah satu ukuran keberhasilan pelayanan keperawatan yang baik adalah seberapa besar produktifitas para perawat dalam memberikan asuhan keperawatan yang baik kepada pasien dan keluarganya. Dengan produktivitas kerja para perawat yang tinggi, maka pelayanan dirumah sakit akan semakin baik, keuntungan dalam organisasi keperawatan akan meningkat dan kepuasan klien sebagai penerima jasa pelayanan keperawatan terpenuhi. Produktivitas secara umum dapat didefinisikan sebagai nilai output dalam hubungannya dengan satuan input tertentu. ${ }^{3}$ Produktivitas kerja perawat (individu) adalah bagaimana individu/perawat melaksanakan pekerjaanya atau unjuk kerja (Job Performance). Produktivitas perawat merupakan hasil dari salah satu sub-variabel kepuasan perawat, kepuasan pasien, pendokumentasian asuhan keperawatan (pengkajian, diagnosa, intervensi, implementasi dan evaluasi) dan komunikasi perawat-pasien. ${ }^{4}$

Rumah Sakit Bhineka Bakti Husada menunjukan hasil evaluasi pendokumentasian asuhan keperawatan disetiap ruang rawat inap nilai rata-rata hasil pendokumentasian keperawatan hanya $80 \%$, hal ini dapat disimpulkan sementara bahwa produktivitas kerja perawat diruang rawat inap masih belum optimal. Jumlah pasien rawat inap pada tahun 2013 didapatkan sejumlah 691 pasien bulan Januari, 683 pasien bulan Februari, 573 pasien bulan Maret, 522 pasien bulan April, 557 pasien bulan Mei, 558 pasien bulan Juni, 489 pasien bulan Juli, 542 pasien bulan Agustus, 531 pasien bulan September, 572 pasien bulan Oktober, 553 pasien bulan November, dan 580 pasien bulan Desember. Dari data tersebut dapat dilihat adanya peningkatan dan penurunan jumlah pasien rawat inap didapatkan selisih sebesar 111 pasien pada bulan Januari dengan bulan Desember. Berdasarkan data yang didapatkan dari kepala bidang keperawatan yaitu hasil evaluasi kerja perawat dan jumlah pasien yang berkunjung di Rumah Sakit Bhineka Bakti Husada bahwa dengan adanya kurang optimalnya pendokumentasian asuhan keperawatan dan juga dapat dilihat adanya penurunan jumlah pasien yang berkunjung di Rumah Sakit Bhineka Bakti Husada, hal ini dapat digambarkan sementara bahwa adanya penurunan produktivitas kerja perawat.

Motivasi perawat yang tidak baik cenderung menghasilkan dokumentasi dengan kualitas yang tidak baik. Pendokumentasian yang tidak dilakukan dengan lengkap dapat menurunkan mutu pelayanan keperawatan karena tidak dapat mengidentifikasi sejauh mana tingkat keberhasilan asuhan keperawatan yang telah diberikan, dalam aspek legal perawat tidak mempunyai bukti tertulis jika klien menuntut ketidakpuasan akan pelayanan keperawatan. Motivasi kerja yang semakin tinggi menjadikan perawat mempunyai semangat yang tinggi untuk memberikan pelayanan yang terbaik. Hal tersebut didukung dengan hasil penelitian yang dilakukan oleh Yanti dan Warsito, ${ }^{5}$ menyatakan bahwa terdapat hubungan antara motivasi dengan kualitas dokumentasi proses asuhan keperawatan. Karena pendokumentasian asuhan keperawatan merupakan salah satu wujud dari produktivitas kerja perawat.

Kualitas dan kemampuan fisik karyawan dan itu dipengaruhi oleh pendidikan, pengalaman, latihan kerja, prestasi, motivasi kerja, kemampuan fisik karyawan, upah kerja, dan sarana pendukung. ${ }^{6}$ Hasil analisa dalam penelitiannya menunjukkan bahwa variabel kemampuan kerja, prestasi kerja, dan upah kerja secara individu berpengaruh positif dan signifikan terhadap produktivitas kerja karyawan. Hasil penelitian Tawale, et $a l^{7}$, didapatkan korelasi antara motivasi kerja perawat dengan kecenderungan mengalami burnout, jika motivasi kerja perawat rendah, maka kecenderungan mengalami burnout pada perawat akan tinggi. Begitu pula sebaliknya jika 
motivasi kerja perawat tinggi, maka kecenderungan mengalami burnout pada perawat akan rendah. Burnout merupakan sindrom dimana seorang perawat merasa kecewa, lelah dan tidak tertarik lagi dengan pekerjaanya. Rendahnya motivasi kerja perawat dapat mengakibatkan adanya burnout sehingga dapat mempengaruhi penurunan produktivitas kerja perawat. Adanya pengaruh positif antara variabel upah, jam kerja dan pengalaman kerja terhadap produktivitas tenaga kerja dalam bidang industry. ${ }^{8}$ Begitu juga penelitian lain, menyatakan bahwa variabel upah yang diterima pekerja berpengaruh signifikan terhadap produktivitas pekerjaan struktur rangkap atap baja ringan di Perumahan Green Hills Malang sebesar $42,4 \% .{ }^{9}$ Kurangnya upah yang didapat dapat menyebabkan tenaga kerja atau seseorang menurun motivasi kerjanya yang akhirnya dapat berdampak pada produktivitas kerjanya.

Data dari bidang keperawatan Rumah Sakit Bhineka Bakti Husada terhadap perawat ruang rawat inap terdapat $20 \%$ perawat kurang melengkapi pendokumentasian asuhan keperawatan. Wawancara 10 perawat RS Bhineka Bakti Husada didapatkan data kurang ada reward dari kepala ruangan terhadap perawat ruang rawat inap sehingga perawat merasa kurang pengakuan terhadap hasil pekerjaannya.Faktor Pendukung lain dalam meningkatkan produktivitas kerja adalah beban kerja. Beban kerja fisik dan beban kerja mental berpengaruh positif terhadap produktivitas. Jika beban kerja fisik karyawan meningkat sebesar satu satuan sementara beban kerja mental karyawan konstan, maka produktivitas karyawan akan meningkat 0,087 satuan. Jika beban mental karyawan meningkat sebesar satu satuan sementara beban kerja fisik karyawan konstan maka produktivitas karyawan akan meningkat 0,740 satuan. ${ }^{10}$

Distribusi penggunaan waktu pelaksanaan kegiatan perawat lebih banyak pada kategori kegiatan lain-lain yaitu selama 42518 detik atau 11 jam 48 menit 38 detik pada shift malam. Salah satu aspek yang sering digunakan untuk melihat kondisi suatu organisasi adalah tingkat kepuasan kerja para anggotanya. Kepuasan kerja rendah menimbulkan dampak negatif seperti produktivitas rendah, kesehatan tubuh menurun. Kepuasan kerja yang rendah dapat disebabkan oleh beban kerja yang dialami oleh para perawat itu sendiri. Hampir sebagian besar akibat yang ditimbulkan oleh beban kerja sangat merugikan. beban kerja yang meningkat dapat menyebabkan penurunan kondisi fisik sehingga berpengaruh terhadap kesehatan. Rumah Sakit Bhineka Bakti Husada memiliki 7 ruang rawat inap, antara lain Ruang Arafah berkapasitas 22 tempat tidur dengan 18 perawat, Ruang Raudah berkapasitas 8 tempat tidur dengan 9 perawat, Ruang Marwah berkapasitas 17 tempat tidur dengan 13 perawat, Ruang Asyifa berkapasitas 21 tempat dengan 14 perawat, Ruang Mustazam berkapasitas 21 tempat tidur dengan 17 perawat, dan Ruang Musdalifah berkapasitas 8 tempat tidur dengan 9 perawat. Selain itu juga didapatkan data yang diperoleh dari kepala bidang keperawatan Rumah Sakit Bhineka Bakti Husada terdapat beberapa perawat yang resign (mengundurkan diri) dari Rumah Sakit pada tahun 2013 ini terdapat 8 orang yang mengundurkan diri. ${ }^{11}$

Data tersebut menunjukkan ketidakseimbangan antara kuantitas tempat tidur dengan jumlah tenaga kerja yang dapat meningkatkan beban tugas perawat dan juga dapat menyebabkan perawat mengalami ketidaknyamanan, ketidaksenangan dalam melakukan proses pelayanan keperawatan. Beban tugas yang diberikan kepada perawat menjadi fluktuatif, hal ini dikarenakan tergantung seberapa banyak jumlah pasien yang dirawat dan seberapa serius perawatan medis pasien yang harus dilakukan.

Kepemimpinan dalam bidang keperawatan dapat dilihat melalui hubungan antara kepala ruangan dan perawat pelaksana. Pemimpin dapat menentukan apakah asuhan keperawatan yang diberikan sudah memenuhi standar atau kepuasan dari klien maupun staf. Komunikasi yang dilakukan oleh kepala ruangan sangat diperlukan agar mampu menciptakan hubungan kerja yang baik dengan bawahan, sehingga tujuan bersama dapat tercapai. Komunikasi merupakan inti dari gaya kepemimpinan kepala ruangan agar mampu meningkatkan motivasi kerja, karena dalam memotivasi perawat pelaksana dibutuhkan pemimpin yang tidak hanya menganggap bawahan sebagai pekerja, tetapi juga sebagai mitra kerja yang memiliki peran dalam organisasi.

Terdapat pengaruh parsial secara positif antara kepemimpinan terhadap produktivitas kerja karyawan pada Como Shambala Estate At Begawan Ubud Bali dengan nilai koefisien regresi dengan sig. $\mathrm{t}=0,018 \quad(\mathrm{p}<0,05) .{ }^{12}$ Pemimpin harus bisa memotivasi kelompok untuk melakukan kerja sama dengan sukarela dan bekerja dengan semangat dan percaya diri 
dengan potensi yang maksimal. Data yang diperoleh oleh bidang keperawatan Rumah Sakit Bhineka Bakti Husada tahun 2013 terdapat jumlah total perawat yang mengundurkan diri sebanyak 8 perawat.

Berdasarkan penjelasan diatas maka gaya kepemimpinan seorang kepala ruangan sangatlah penting dalam menumbuhkan atau meningkatkan produktivitas kerja perawat. Adapun tujuan dari penelitian ini adalah untuk mengetahui pengaruh langsung dan tidak langsung serta besaran beban kerja, motivasi kerja, dan kepemimpinan kepala ruangan terhadap produktivitas kerja perawat Ruang Rawat Inap di Rumah Sakit Bhineka Bakti Husada Tanggerang Selatan 2015.

\section{Metode}

Penelitian ini dilakukan dengan rancangan cross-sectional melalui pendekatan kuantitatif yang dilaksanakan di Rumah Sakit Bhineka Bakti Husada yang dilaksanakan bulan Desember 2014 dan Januari 2015. Populasi merupakan perawat yang bekerja diruang rawat inap sebanyak 80 dengan jumlah sampel 80 responden melalui total sampling yang memiliki kriteria inklusi perawat yang bekerja diruang rawat inao Rumah Sakit Bhineka Bakti Husada, bersedia menjadi subjek penelitian. ${ }^{13}$

Skala pengukuran pada penelitian ini ada dua yang mana untuk variabel kepemimpinan kepala ruangan menggunakan skala semantic differential yang dikembangkan oleh Osgood yang memiliki 5 point pada skala ini jawaban "sangat positifnya" berada paling kanan garis bawah dan jawaban "sangat negatifnya" berada paling bawah kiri garis sedangkan untuk variabel motivasi kerja dan beban kerja kemudian dikonversi kedalam nilai 1 sampai dengan 5. Data yang diperoleh data interval. Responden yang memilih angka 5 berarti nilainya sangat positif, sedangkan memilih angka 3 berarti nilainya netral, dan bila memilih angka 1 berarti nilainya sangat negative. ${ }^{14}$

Data primer yang digunakan dalam penelitian ini melalui alat bantu (instrument) berarti angket/pertanyaan diperoleh melalui penyebaran kuisioner yang berisi 3 variabel dengan 9 indikator yang mana setiap indikator memiliki 5 peryataan sehingga total peryataan dalam kuisioner berjumlah 45. Sedangkan data sekunder pada variabel dependen didapatkan dari evaluasi pendokumentasian perawat yang dinilai langsung oleh kepala bagian keperawatan RS BBH.

Uji validitas dan realibilitas dilakukan untuk mengetahui apakah instrument yang digunakan untuk penelitian telah dapat mengukur apa yang harus diukur dan sejauh mana instrument yang digunakan dipercaya untuk penelitian. Uji validitas dan realibilitas pada butir instrument penelitian menggunakan SPSS sebelum disebar untuk penelitian. Sedangkan uji validitas dan realibilitas variabel endogen dan eksogen menggunakan PLS. Loading Faktor menurut beberapa ahli harus diatas 0,5. Sedangkan nilai composite realibility mengukur internal consistency dan nilainya harus diatas 0,7 dan nilai average variance exctracted (AVE) harus diatas $0,5 .^{15}$

Kuisioner dalam penelitian ini telah diujikan terlebih dahulu pada perawat di ruang rawat inap Rumah Sakit Permata Pamulang yang berjumlah 30 orang. Dengan jumlah sampel 30 orang, $\mathrm{df}=28$ maka didapatkan $\mathrm{r}$ tabel 0,361 . Jika $r$ hitung lebih besar dari $r$ tabel dinyatakan valid, sedangkan realibilitas dapat dilihat pada kolom Cronbach's Alpha if Item deleted, jika nilainya $>0,7$, maka dinyatakan realibel.

Dalam penelitian ini analisis data menggunakan pendekatan PLS dengan menggunakan software smartPLS. PLS adalah model persamaan menggunakan persamaan SEM (Structural Equation Models) atau model persamaan structural, yaitu sebuah model statistik yang memberikan perkiraan perhitungan dari kekuatan hubungan hipotesis antar variabel dalam sebuah model teoritis baik secara langsung atau melalui variabel antara (intervening or mediating variabels). ${ }^{16}$ Model hubungan semua variabel laten dalam PLS terdiri dari tiga ukuran,yaitu: ${ }^{15}$ (1) Inner model yang menspesifikasi hubungan antar variabel laten (structural model) yang menggambarkan hubungan antar variabel laten berdasarkan pada substansive theory; (2) Outer model sering juga disebut outer relation yang mendefinisikan bagaimana setiap blok indikator berhubungan dengan variabel latennya.

Data yang disajikan pada awal hasil analisa berupa gambaran mengenai sampel, dimana terdapat tabel yang disertai penjelasan untuk membantu pembaca mengenal karakteristik responden. Hasil analisa SEM dari pengolahan data output yang menggunakan SmartPLS 2.0 disajikan dalam bentuk tabel dan lain-lain. 
Penyajian yang lebih lengkap akan dilampirkan. Sedangkan oengujian hipotesis berdasarkan dari keluaran hasil pengolahan data.

\section{Hasil}

Dalam penelitian ini mencakup 80 responden yaitu seluruh perawat ruang rawat inap di Rumah Sakit Bhineka Bakti Husada tahun 2015. Variabel yang diukur dalam penelitian ini adalah variabel motivasi kerja, beban kerja, kepemimpinan kepala ruangan dan produktivitas kerja. Sebagian besar responden adalah berumur 20-23 tahun sebanyak 40 (50\%) responden. Berdasarkan pendidikan responden memperlihatkan bahwa sebagian besar responden adalah berpendidikan D3 Keperawatan, yaitu sebanyak $71 \quad(88,8 \%)$ responden. Sedangkan berdasarkan lama kerja responden memperlihatkan bahwa sebagian besar responden ada pada rentang lama kerja 1 tahun yaitu sebanyak 34 (42,5\%) responden.

Hasil uji Chi-Square, variasi karakteristik responden tidak ada yang berhubungan dengan jawaban atas pernyataan dari beban kerja, motivasi kerja dan kepemimpinan kepala ruangan karena $P_{\text {value }}>0,05$.

Model pengukuran atau outer model dengan indikator refleksif dievaluasi dengan convergent dan discriminant validity dari indikatornya, composite reliability untuk blok indikator, dan $A V E$, serta nilai composite reliability. Sedangkan outer model dengan formatif indikator dievaluasi berdasarkan substantive content-nya, yaitu dengan membandingkan besarnya relatif weight dan melihat signifikansi dari ukuran weight tersebut. Hasil faktor loading indikator terhadap masingmasing variabelnya dapat dilihat pada gambar di bawah ini. Berikut output hasil run awal:

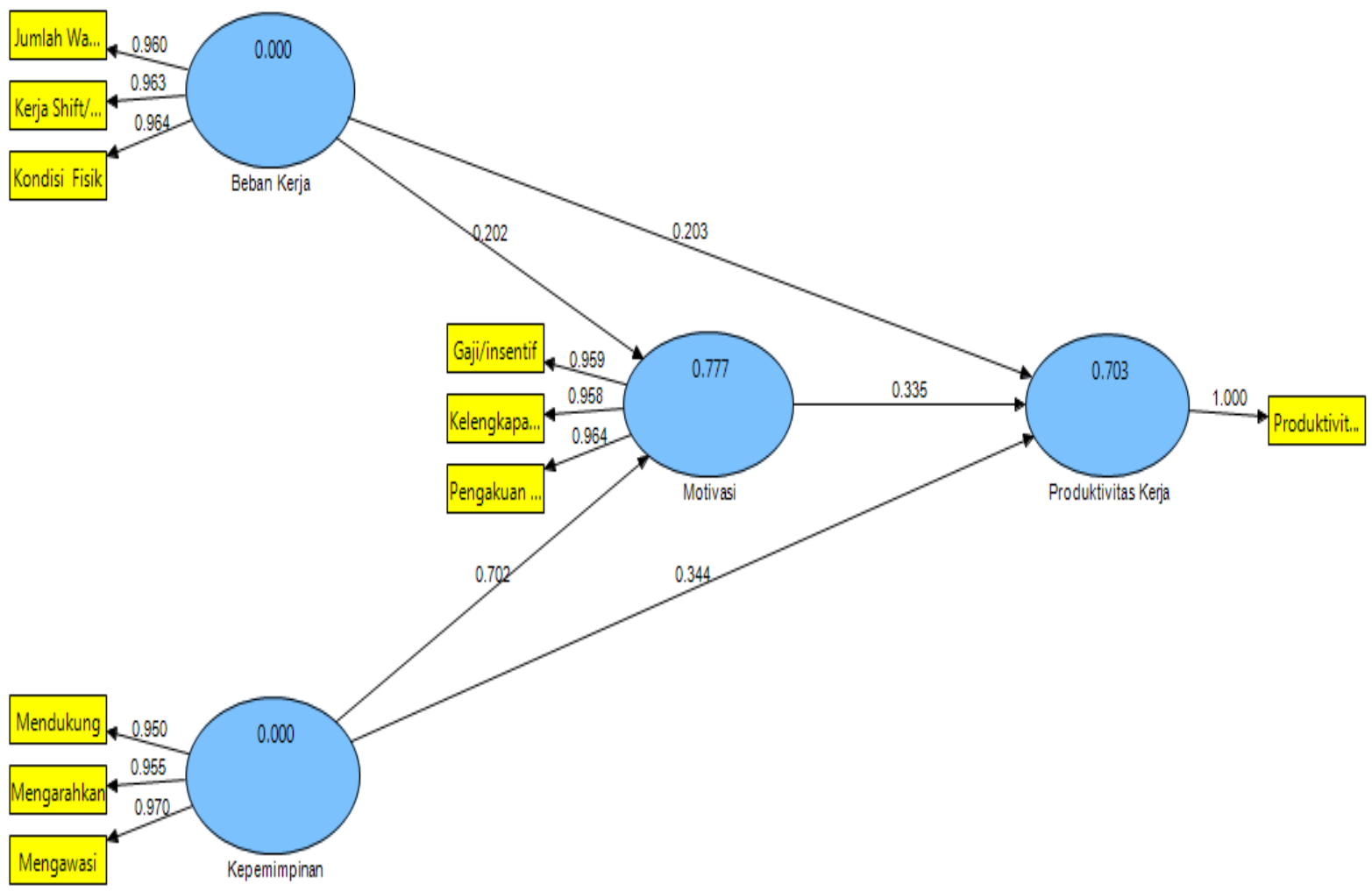

Gambar 1

Output PLS (Loading Factors)

Tujuan cross loading adalah untuk mengetahui apakah variabel mampu memprediksi lebih tinggi faktor loading indikatornya dibandingkan prediksi terhadap indikator lainnya dengan melihat nilai cross loading. Selain itu, untuk melihat validitas indikator yang digunakan dalam penelitian dapat dilakukan dengan mengevaluasi hasil cross loading semua indikator. Suatu indikator dinyatakan valid jika mempunyai loading factor tertinggi kepada konstruk yang dituju dibandingkan loading factor kepada konstruk lain, bahwa korelasi konstruk lebih besar dari 
pada ukuran konstruk lainnya. Hal itu menunjukkan bahwa konstruk laten memprediksi ukuran pada bloknya lebih baik dari pada ukuran pada blok lainnya. Suatu indikator reflektif dinyatakan valid jika mempunyai loading factor di atas 0,5 terhadap konstruk yang dituju berdasarkan pada substantive content-nya dengan melihat signifikansi dari weight $(\mathrm{t}=1,96)$. Berdasarkan gambar di atas menunjukkan bahwa semua konstruk memiliki nilai faktor loading lebih besar dari 0,5 sehingga kriteria uji terhadap indikator ukur dinyatakan semua valid.Nilai akar $A V E$ telah lebih besar dari pada nilai korelasi antar variabel laten dengan nilai $>0,8$ dan nilai composite realibility $>0,8$ dimana standar yang ditetapkan $>0,7$ serta uji reabilitas yang diperkuat dengan Cronbach alpha didapatkan $>0,8$ dimana nilai yang diharapkan $>0,7$ untuk semua konstruk. Sehingga dapat dikatakan. penelitian ini memiliki tingkat validitas dan realibilitas yang baik.

Hasil evaluasi signifikan outer model diatur dalam output PLS di bawah ini dengan mengevaluasi refleksi nilai $T$-statistic indikator terhadap variabelnya. Evaluasi signifikansi outer model dilakukan untuk menilai signifikansi konstruk laten dengan konstruknya, yaitu dengan membandingkan nilai $t$ statistik masing-masing konstruk laten dengan nilai $\alpha=$ $0,05(1,96)$. Untuk mengukur nilai $\mathrm{t}$ statistik dilakukan bootstrapping pada model dengan hasil sebagai berikut:

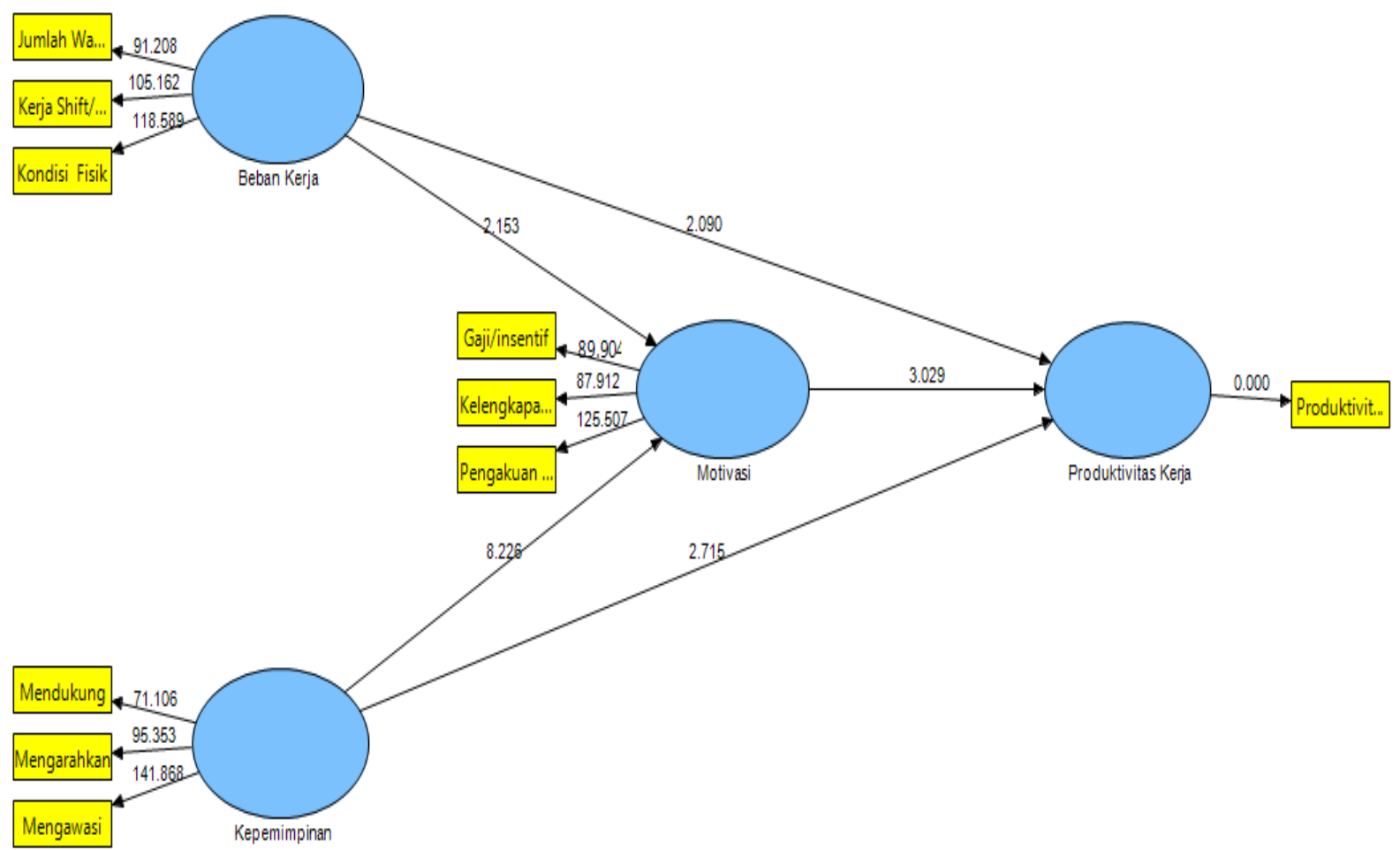

Gambar 2

Output PLS (T-Statistic)

Untuk melihat uji hipotesis terhadap indikator dari variabel yang diteliti, dapat dilihat pada Gambar 2 yang menunjukan bahwa setelah dilakukan bootstrapping untuk mengukur nilai $\mathrm{t}$ statistik dari masing-masing konstruk laten terhadap konstruknya, maka nilai t statistik dibandingkan dengan nilai $\alpha=0,05(1,96)$. Ketentuannya, apabila nilai $\mathrm{t}$ statistik lebih besar dari nilai $\alpha=0,05(1,96)$, maka konstruk laten tersebut signifikan terhadap konstruknya. hasil pengukuran nilai $\mathrm{t}$ statistik dari setiap indikator ke variabel lebih besar dari 1,96 dengan tingkat kepercayaan $95 \%(\alpha=0,05)$. Hal itu berarti, semua indikator berpengaruh secara signifikan terhadap variabel yang diteliti.

Untuk uji hipotesis antar variabel, terlihat bahwa beban kerja berpengaruh positif terhadap motivasi kerja. Hasil uji terhadap koefisien parameter antara beban kerja terhadap motivasi kerja menunjukkan ada pengaruh positif 
0,202399, sedangkan nilai T-Statistic sebesar 2,153007 dan signifikan pada $\alpha=5 \%$. Nilai $T$ Statistic tersebut berada di atas nilai kritis $(1,96)$. Kemudian juga menyatakan bahwa beban kerja berpengaruh positif terhadap produktivitas kerja. Hasil uji terhadap koefisien parameter antara beban kerja terhadap produktivitas kerja menunjukkan ada pengaruh positif 0,202929 , sedangkan nilai T-Statistic sebesar 2,090437 dan signifikan pada $\alpha=5 \%$. Nilai T-Statistic tersebut berada di atas nilai kritis $(1,96)$. Selanjutnya juga menyatakan bahwa kepemimpinan berpengaruh positif terhadap motivasi kerja. Hasil uji terhadap koefisien parameter antara kepemimpinan terhadap motivasi kerja menunjukkan ada pengaruh positif 0,701514 , sedangkan nilai $T$ Statistic sebesar 8,225881 dan signifikan pada $\alpha=5 \%$. Nilai $T$-Statistic tersebut berada jauh diatas nilai kritis $(1,96)$. Kemudian juga menyatakan bahwa kepemimpinan berpengaruh positif terhadap produktivitas kerja. Hasil uji terhadap koefisien parameter antara kepemimpinan terhadap produktivitas kerja menunjukkan ada pengaruh positif 0,343865 , sedangkan nilai $T$-Statistic sebesar 2,714944 dan signifikan pada $\alpha=5 \%$. Nilai T-Statistic tersebut berada di atas nilai kritis $(1,96)$. Selanjutnya juga menyatakan bahwa motivasi kerja berpengaruh positif terhadap produktivitas kerja. Hasil uji terhadap koefisien parameter antara motivasi kerja terhadap produktivitas kerja menunjukkan ada pengaruh positif 0,335423 , sedangkan nilai $T$-Statistic sebesar 3,028739 dan signifikan pada $\alpha=5 \%$. Nilai $T$ Statistic tersebut berada jauh diatas nilai kritis $(1,96)$.

Inner model disebut juga dengan nilai $R$ Square, uji hipotesis T-Statistik, pengaruh variabel langsung dan prediktif (nilai $Q$ Square). Nilai square berfungsi untuk menilai besaran keragaman atau variasi data penelitian terhadap fenomena yang sedang dikaji. Pengujian terhadap model struktural dilakukan dengan melihat nilai $R$-Square yang merupakan uji goodness-fit model. Uji yang kedua adalah melihat signifikansi pengaruh antar konstruk. Berikut ini adalah hasil pengukuran nilai $R$ Square, yang juga merupakan nilai goodness of fit model. Berikut hasil output-nya dalam bentuk tabel, yaitu:

Tabel 1. Nilai R Square

\begin{tabular}{cc}
\hline Variabel & R Square \\
\hline Beban Kerja & \\
Kepemimpinan & \\
Motivasi & 0,776600 \\
Produktivitas Kerja & 0,702920 \\
\hline
\end{tabular}

Berdasarkan tabel di atas, beban kerja dan kepemimpinan berkontribusi terhadap motivasi sebesar 0,776600, dan beban kerja, kepemimpinan, serta motivasi berkontribusi terhadap produktivitas kerja sebesar 0,702920. Berdasarkan hasil pengukuran tersebut dapat disimpulkan bahwa variabilitas konstrak motivasi mampu dijelaskan oleh variabilitas beban kerja dan kepemimpinan sebesar 77,66\% dan $22,34 \%$ dijelaskan oleh variabel lain yang tidak diteliti. Sedangkan variabilitas konstrak produktivitas kerja mampu dijelaskan oleh variabilitas beban kerja, kepemimpinan, serta motivasi sebesar 70,29\% dan 29,71\% dijelaskan oleh variabel lain yang tidak diteliti.

Setelah diketahui $R$-Square dan Path Coeficient, selanjutnya dilakukan pengukuran untuk mengetahui besaran pengaruh langsung dan tidak langsung antar variabel dengan hasil sebagai berikut:

Tabel 2. Pengaruh Langsung dan Tidak Langsung antar Variabel

\begin{tabular}{cccccccc}
\hline Sumber & $\begin{array}{c}\boldsymbol{L} \boldsymbol{V} \\
\text { Correlation }\end{array}$ & $\begin{array}{c}\text { Direct } \\
\text { Rho }\end{array}$ & $\begin{array}{c}\text { Inderect } \\
\text { Rho }\end{array}$ & Total & $\begin{array}{c}\text { Direct } \\
\text { \% }\end{array}$ & $\begin{array}{c}\text { Indirect } \\
\text { \% }\end{array}$ & $\begin{array}{c}\text { Total } \\
\text { \% }\end{array}$ \\
\hline Beban Kerja & 0,767 & 0,203 & 0,034 & 0,237 & 15,570 & 2,174 & 17,744 \\
Kepemimpinan & 0,811 & 0,344 & 0,118 & 0,462 & 27,898 & 8,221 & 36,119 \\
Motivasi & 0,799 & 0,335 & 0 & 0,335 & 26,767 & 0 & 26,767 \\
\hline \multicolumn{3}{c}{ Total } & & $\mathbf{7 0 , 2 3 5}$ & $\mathbf{1 0 , 3 9 4}$ & $\mathbf{8 0 , 6 2 9}$ \\
\hline
\end{tabular}


Dari tabel di atas menyatakan bahwa beban kerja berpengaruh secara langsung dan tidak langsung terhadap produktivitas kerja. Hasil uji koefisien parameter antara beban kerja terhadap produktivitas kerja menunjukkan terdapat pengaruh langsung sebesar $15,57 \%$, sedangkan untuk pengaruh tidak langsung antara beban kerja terhadap produktivitas kerja melalui motivasi didapat dengan mengalikan koefisien jalur (beban kerja $\rightarrow$ motivasi) x LV (beban kerja $\rightarrow$ motivasi) dengan koefisien jalur (motivasi $\rightarrow$ produktivitas kerja) $\mathrm{x}$ LV (motivasi $\rightarrow$ produktivitas kerja) sehingga mendapat nilai sebesar $2,17 \%$.

Dari tabel tersebut menyatakan bahwa motivasi berpengaruh secara langsung terhadap produktivitas kerja. Hasil uji koefisien parameter antara motivasi terhadap produktivitas kerja menunjukkan terdapat pengaruh langsung sebesar 26,77\%.

Kepemimpinan berpengaruh secara langsung dan tidak langsung terhadap produktivitas kerja. Hasil uji koefisien parameter antara kepemimpinan terhadap produktivitas kerja menunjukkan terdapat pengaruh langsung sebesar $27,90 \%$, sedangkan untuk pengaruh tidak langsung antara kepemimpinan terhadap produktivitas kerja melalui motivasi didapat dengan mengalikan koefisien jalur (kepemimpinan $\rightarrow$ motivasi) $\mathrm{x}$ LV (kepemimpinan $\rightarrow$ motivasi) dengan koefisien jalur (motivasi $\rightarrow$ produktivitas kerja) $\mathrm{x} \mathrm{LV} \mathrm{(motivasi} \rightarrow$ produktivitas kerja) sehingga mendapat nilai sebesar $8,22 \%$.

Sehingga nilai dari masing-masing pengaruh langsung variabel laten independen tersebut apabila secara bersama-sama menunjukkan kesesuaian dengan nilai $R$ Square atau dengan kata lain hal ini menyatakan bahwa variabel beban kerja, motivasi, dan kepemimpinan mampu menjelaskan variabel produktivitas kerja sebesar $(15,570+27,898+$ $26,767)=70,235$.

Persamaan matematika yang sesuai dengan analisis diatas, yaitu:

$$
\eta 1=\gamma 1 . \xi 1+\gamma 2 . \xi 2+\zeta 1
$$

Motivasi $=0,202 \times$ Beban Kerja $+0,702 \times$ Kepemimpinan $+0,223$

$$
\mathrm{Y}=\gamma 3 . \xi 1+\gamma 4 . \xi 2+\beta 1 . \eta 1+\zeta 2
$$

Produktivitas Kerja $=0,203 \times$ Beban Kerja + 0,344 x Kepemimpinan + $0,335 \times$ Motivasi $+0,297$

Kesimpulannya, Produktivitas kerja perawat di Ruang Rawat Inap Rumah Sakit Bhineka Bakti Husada tahun 2015 dipengaruhi oleh beban kerja sebesar 0,203, dipengaruhi oleh kepemimpinan sebesar 0,344, dan dipengaruhi oleh faktor lain sebesar 0,297 artinya terdapat pengaruh yang positif dari beban kerja, kepemimpinan, dan motivasi, semakin rendah beban kerja, dan semakin baik kepemimpinan, serta semakin tinggi motivasi maka akan semakin meningkat pula produktivitas kerja perawat di di Ruang Rawat Inap Rumah Sakit Bhineka Bakti Husada tahun 2015.

Sedangkan Predictive Relevance (Nilai $Q$ Square)

$$
\begin{array}{ll}
Q^{2} & =1-\left(1-\mathrm{R}_{1}{ }^{2}\right)\left(1-\mathrm{R}_{2}{ }^{2}\right) \\
Q^{2} & =1-(1-0,777)(1-0,703) \\
Q^{2} & =0,933769 \Rightarrow 93,38 \%
\end{array}
$$

Hal ini menunjukan bahwa model hasil analisis dapat menjelaskan 93,38\% keragaman data dan mampu mengkaji fenomena yang dipakah dalam penelitian, sedangkan $6,62 \%$ dijelaskan oleh variabel lain yang tidak dikaji dalam penelitian ini.

\section{Pembahasan}

\section{Pengaruh Antara Variabel Motivasi Kerja terhadap Produktivitas Kerja}

Hasil penelitian yang dilakukan di RS BBH Tangerang selatan, bahwa dari ketiga indikator ukur yang dimiliki variabel motivasi kerja semua indikator mampu menjelaskan variabel motivasi kerja. Hasil uji hipotesis terhadap koefisien parameter antara motivasi kerja terhadap produktivitas kerja menunjukkan ada pengaruh positif 0,335423 , sedangkan nilai T-Statistic sebesar 3,028739 dan signifikan pada $\alpha=5 \%$. Nilai $T$-Statistic tersebut berada jauh diatas nilai kritis $(1,96)$.

Hasil penelitian ini didukung dengan Teori Maslow, "Hirarki Kebutuhan" Maslow memandang kebutuhan manusia berdasarkan suatu hirarki kebutuhan dari kebutuhan yang paling rendah hingga kebutuhan yang paling tinggi. 
Peran motivasi kerja terhadap produktitas dapat meningkatkan semangat kerja karyawan dimana karyawan akan bekerja secara maksimal dan menyukai lingkungan kerjanya dan keuntungan yang didapat dalam suatu perusahaan adalah mendapatkan penghasilan yang meningkat dari tahun ke tahun apabila motivasi ini terus dilakukan. ${ }^{16}$

Hasil penelitian ini didukung juga oleh penelitian Mudayana, ${ }^{17}$ bahwa ada hubungan antara motivasi dengan kualitas dokumentasi proses asuhan keperawatan dengan hasil uji statistik diperoleh P-value 0,036. Penelitian ini sejalan dengan hasil uji hipotesis bahwa motivasi kerja berpengaruh positif terhadap produktivitas kerja perawat. Motivasi yang sangat tinggi menjadikan perawat mempunyai semangat tinggi untuk memberikan pelayanan terbaik sehingga dapat meningkatkan produktivitas kerja perawat berupa asuhan keperawatan.

Timbulnya motivasi untuk berperilaku karena dipengaruhi oleh kebutuhan-kebutuhan yang ada dalam diri manusia (kebutuhan kekuasaan, kebutuhan afiliasi/kebutuhan mencari atau mempertahankan relasi interpersonal, dan kebutuhan berprestasi. Menurut penelitian yang diungkapkan oleh Brasit et al,bahwa variabel motivasi merupakan variabel yang paling berpengaruh terhadap produktivitas perawat disebabkan karena semua masalah yang ada pada variabel motivasi mencakup semua masalah - masalah yang terdapat pada variabel yang berpengaruh pada penelitian ini (kemampuan, persepsi dan pembelajaran individu) membentuk motivasi perawat menjadi motivasi negative sehingga perawat memiliki motivasi yang kurang baik untuk meningkatkan produktivitasnya sebagaimana standar PPNI. Mulai dari masalah kondisi lingkungan dan system manajemen rumah sakit yang buruk, banyak ditemukan ketidak lengkapan pendokumentasian rekam medis/dokumentasi keperawatan, jarangnya dilakukan personal hygine kepada pasien, masih banyak perawat yang belum menerapkan MPKP, kadang terjadi konflik antar sesama perawat, hingga sampai ke permasalahan minimnya pembelajaran individu yang diperoleh perawat selama bekerja di rumah sakit tersebut sehingga berangkat dari persepsi yang buruk maka perawat kurang termotivasi untuk meningkatkan produktivitasnya terutama persoalan keterlambatan pembayaran insentif mereka.

\section{Pengaruh Antara Variabel Beban Kerja terhadap Produktivitas Kerja}

Hasil penelitian yang dilakukan di RS BBH Tangerang selatan, bahwa dari ketiga indikator ukur yang dimiliki variabel beban kerja semua indikator mampu menjelaskan variabel beban kerja.dari hasil uji hipotesis menyatakan bahwa beban kerja berpengaruh positif terhadap produktivitas kerja. Hasil uji terhadap koefisien parameter antara beban kerja terhadap produktivitas kerja menunjukkan ada pengaruh positif 0,202929, sedangkan nilai T-Statistic sebesar 2,090437 dan signifikan pada $\alpha=5 \%$. Nilai T-Statistic tersebut berada di atas nilai kritis $(1,96)$.

Penelitian ini menyatakan bahwa beban kerja meningkat sehingga produktivitas kerja juga meningkat. Hal ini dapat dilihat dari lamanya perawat yang bekerja di RS BBH dominan banyak yang bekerja kurang dari 1 tahun sampai dengan 1 tahun sehingga dengan banyaknya beban kerja yang diterima oleh perawat maka keinginan perawat dalam berproduktif masih tinggi. Selain itu juga dapat dilihat dari usia perawat yang dominan berkisar 20 sampai 23, dimana usia seperti ini usia-usia yang berproduktif sehingga produktivitas kerja perawat dapat meningkat walaupun beban kerja yang diterima banyak.

Hal ini sesuai dengan apa yang disampaikan oleh Djiuta, ${ }^{8}$ bahwa variabel jam kerja/shift kerja yang merupakan indikator dari beban kerja yaitu berpengaruh positif terhadap produktivitas tenaga kerja dimana nilai $\mathrm{T}$ hitung lebih besar dari nilai $\mathrm{T}$ tabel pada level $\alpha=0,05$. Produktivitas kerja seseorang bisa berbeda walaupun dengan jumlah jam kerja yang sama. Hal ini dikarenakan skill dan tehnologi yang digunakan dan pengaruh jam kerja terhadap produktivitas tenaga kerja bisa positif dan bisa juga negatif. Akan tetapi untuk tenaga kerja perawat dalam penelitian ini berpengaruh positif terhadap produktivitas kerja perawat. ${ }^{8}$

Selain itu juga menurut penelitian yang dilakukan Minarsih, ${ }^{18}$ bahwa Uji statistik ChiSquare menunjukkan adanya hubungan yang bermakna antara beban kerja perawat dengan produktivitas kerja perawat dengan nilai $\mathrm{p}=$ $0,000(\mathrm{p}<0,005)$ dan dengan kata lain Ho ditolak. Berdasarkan analisis hasil penelitian ini, 
yang merasakan beban waktu bersifat berat adalah responden 66 yang merasakan beban kerja di ruangan terlalu memberatkan, sering membutuhkan waktu ekstra diruangan untuk menyelesaikan tugas keperawatan dan perawat yang merasa sulit mengatur jadwal dinas bila membutuhkan waktu libur. Mereka juga sering diminta untuk masuk secara mendadak bila ada perawat yang tidak masuk karena ada halangan, biasanya yang sering terjadi juga adalah perawat senior sering datang terlambat saat akan operan, sehingga waktu kerja mereka menjadi bertambah.

Beban waktu kerja lebih mempertimbangkan pada aspek pengunaan waktu untuk bekerja, yaitu sebagai alokasi penggunaan waktu guna peningkatan pelayanan keperawatan terhadap pasien. Waktu kerja berkaitan dengan waktu yang digunakan untuk mengerjakan tugasnya sesuai dengan jam kerja yang berlangsung setiap hari. ${ }^{19}$ Beban kerja merupakan salah satu unsur yang harus diperhatikan bagi seorang tenaga kerja untuk mendapatkan keserasian dan produktivitas kerja yang tinggi selain unsur beban tambahan akibat lingkungan kerja dan kapasitas kerja. Selain itu Beban kerja juga berkaitan erat dengan produktifitas tenaga kesehatan, dimana 53,2\% waktu yang benar-benar produktif yang digunakan pelayanan kesehatan langsung dan sisanya $39,9 \%$ digunakan untuk kegiatan penunjang.

\section{Pengaruh Antara Variabel Kepemimpinan terhadap Produktivitas Kerja}

Kepemimpinan merupakan masalah yang sangat penting dalam manajemen dan organisasi. Bahkan ada yang menyatakan bahwa kepemimpinan merupakan jantung atau intinya manajemen dan organisasi. Tidak jarang seorang pemimpin dibenci oleh karyawannya sehingga hal ini bisa memicu ketidak harmonisan, konflik internal, motivasi kerja sampai pencapaian produktivitas kerja yang menurun.

Kepemimpinan dalam keperawatan dapat ditumbuhkan lebih optimal dengan menguasai keterampilan dalam menghadapi orang lain dengan efektif. Kepemimpinan efektif merupakan gaya memimpin yang dapat menghasilkan keluaran melalui pengaturan kinerja orang lain. Pemimpin harus memastikan bahwa bawahan melaksanakan pekerjaannya berdasarkan keterampilan dan komitmen yang 559 dimiliki terhadap pekerjaan untuk menghasilkan keluaran yang terbaik, maka Gaya kepemimpinan sangat mempengaruhi produktifitas kerja.

Dari ketiga indikator ukur yang dimiliki variabel kepemimpinan kepala ruangan semua indikator mampu menjelaskan variabel kepemimpinan kepala ruangan. Dari hasil uji hipotesis menyatakan bahwa kepemimpinan berpengaruh positif terhadap produktivitas kerja. Hasil uji terhadap koefisien parameter antara kepemimpinan terhadap produktivitas kerja menunjukkan ada pengaruh positif 0,343865 , sedangkan nilai $T$-Statistic sebesar 2,714944 dan signifikan pada $\alpha=5 \%$. Nilai TStatistic tersebut berada di atas nilai kritis $(1,96)$.

Berdasarkan penelitian Wartana, ${ }^{12}$ bahwa kepemimpinan secara parsial memiliki pengaruh positif terhadap produktivitas kerja karyawan dengan hasil koefisien regresi sig.t $=0,018$ $(p<0,05)$. Kepemimpinan merupakan hal yang penting perananya untuk meningkatkan produktivitas kerja karyawannya.

Selain itu menurut penelitian Sumarni, ${ }^{20}$ bahwa adanya hubungan yang bermakna antara efektivitas kepemimpinan dengan produktivitas kerja perawat. Kepala ruangan sebagai penanggung jawab ruang rawat inap mempunyai peranan yang sangat menentukan di dalam menciptakan pelayanan keperawatan yang profesional, dengan mengarahkan, menggerakkan, memberi kemudahan dan memberi teladan yang baik bagi perawat pelaksana agar mempunyai motivasi yang tinggi untuk bekerja secara produktif, sehingga dapat meningkatkan produktivitas kerja perawat.

\section{Pengaruh Antara Variabel Beban Kerja terhadap Motivasi Kerja}

Hasil penelitian yang dilakukan di RS $\mathrm{BBH}$, bahwa dari ketiga indikator ukur yang dimiliki variabel beban kerja semua indikator mampu menjelaskan variabel beban kerja dari hasil uji hipotesis menyatakan bahwa beban kerja berpengaruh positif terhadap motivasi kerja. Hasil uji terhadap koefisien parameter antara beban kerja terhadap motivasi kerja menunjukkan ada pengaruh positif 0,202399, sedangkan nilai T-Statistic sebesar 2,153007 dan signifikan pada $\alpha=5 \%$. Nilai T-Statistic tersebut berada di atas nilai kritis $(1,96)$. 
Hasil penelitian ini mengatakan bahwa beban kerja meningkat dapat meningkatkan motivasi kerja perawat, hal ini dapat dilihat dari seorang perawat yang lama bekerjanya kurang dari 1 sampai dengan 1 tahun beban kerja yang meningkat tidak bermasalah bagi perawat mealinkan dengan banyaknya beban kerja yang meningkat dapat membuat perawat tersebut dapat mendapatkkan pengalaman yang banyak dan dapat meningkatkan skill seorang perawat sehingga motivasi kerja perawat tersebut dapat meningkat.

Selain itu juga dapat dilihat dari usia perawat yang dominan mempunyai usia 20 sampai dengan 23 dimana usia seperti ini usia yang mencari pengalaman yang lebih untuk mendapatkan ilmu dan pengalaman yang berlebih sehingga motivasi kerja perawat dapat meningkat.

Hasil penelitian tidak berbanding terbalik oleh pendapat Crayon yaitu bila beban kerja terlalu tinggi akan menyebabkan komunikasi yang buruk antara perawat dan pasien, kegagalan kolaborasi perawat dan dokter, tingginya droup out perawat/turn over dan rasa ketidak puasan perawat sehingga motivasi kerja perawat rendah.

Berdasarkan hasil penelitian yang dilakukan oleh Widyastuti, ${ }^{21}$ tidak sejalan dengan penelitian yang didapat bahwa hasil uji hubungan beban kerja dan motivasi kerja perawat pelaksana didapatkan $\mathrm{p}$ value $=0.856$ artinya tidak terdapat hubungan yang signifikan antara beban kerja dengan motivasi kerja perawat pelaksana di Rumah Sakit Premier Surabaya.

\section{Pengaruh Antara Variabel kepemimpinan terhadap Motivasi Kerja}

Hasil penelitian yang dilakukan di RS $\mathrm{BBH}$, bahwa dari ketiga indikator ukur yang dimiliki variabel kepemimpinan kepala ruangan semua indikator mampu menjelaskan variabel kepala ruangan dari hasil uji hipotesis menyatakan bahwa kepemimpinan berpengaruh positif terhadap motivasi kerja. Hasil uji terhadap koefisien parameter antara kepemimpinan terhadap motivasi kerja menunjukkan ada pengaruh positif 0,701514, sedangkan nilai T-Statistic sebesar 8,225881 dan signifikan pada $\alpha=5 \%$. Nilai T-Statistic tersebut berada jauh diatas nilai kritis $(1,96)$.
Hasil penelitian ini mengatakan bahwa kepemimpinan yang baik dapat meningkatkan motivasi kerja perawat. Hal ini dapat dilihat dari seorang pemimpin yang dapat mengarahkan, mendukung dan mengawasi secara baik maka seorang perawat dapat termotivasi dengan baik untuk dapat meningkatkan skill dan pengetahuannya.

Berdasarkan penelitian yang dilakukan oleh Hardiansa, ${ }^{22}$ bahwa adanya Hubungan yang signifikan antara Gaya kepemimpinan kepala ruang dengan motivasi kerja perawat di RSUD Ambarawa dengan nilai $\mathrm{p}$-vallue $=0,008$ $<\alpha(0,05)$, dengan nilai $\tau=0,506$ arah korelasi positif. Dari nilai korelasi yang didapatkan arah korelasi adalah positif yang dimana tingkat hubungan dari dua variabel independent dan variabel dependent sedang. Dengan tingkat hubungan yang sedang maka motivasi kerja perawat dapat dipengaruhi oleh beberapa faktor lain.

Penelitian ini juga sejalan dengan penelitian yang dilakukan oleh Palangdeng et $a l,{ }^{23}$ bahwa hasil analisis menggunakan uji statistik fisher's exact test diperoleh nilai $\mathrm{p}=$ 0,003 , atau probabilitas di bawah $0,05(0,003<$ $0,05)$ dari analisis tersebut menunjukkan terdapat hubungan kepemimpinan kepala ruangan menurut persepsi perawat tentang motivasi kerja perawat pelaksana di ruang Instalasi rawat Inap F BLU RSUP Prof.Dr.R.D.Kandou Manado.

Hal ini juga sependapat dengan penelitian yang dilakukan oleh Arta, ${ }^{24}$ bahwa hasil analisis uji spearman rank $(\rho)$ didapatkan nilai significancy (p) adalah 0.015 berarti nilai $\mathrm{p}<$ 0,05, maka Ho ditolak yang berarti ada pengaruh yang bermakna antara gaya kepemimpinan kepala ruangan terhadap motivasi kerja perawat dalam melaksanakan asuhan keperawatan di Irna C RSUP Sanglah. Sedangkan nilai koefisien korelasi ( $\rho)$ yang didapat adalah 0.289 , termasuk pada kategori lemah. Dapat disimpulkan bahwa pengaruh gaya kepemimpinan kepala ruangan terhadap motivasi kerja perawat dalam melaksanakan asuhan keperawatan adalah lemah.

Pemimpin yang baik adalah pemimpin yang dapat membina hubungan antar manusia, meliputi kemampuan untuk bekerja sama dengan orang lain, termasuk memotivasi dan menerapkan kepemimpinan yang efektif. motivasi harus diberikan pimpinan terhadap 
bawahannya karena sering kali ada bawahan yang mampu mengerjakan pekerjaanya tetapi ia malas atau kurang bergairah untuk mengerjakannya. Dalam hal ini kepala ruangan selaku pemimpin berperan penting dalam mengidentifikasi, menumbuhkan dan mengarahkan motivasi perawat agar mau dan antusias dalam bekerja, karena kepala ruangan yang mengalami kontak langsung dengan staf di ruangan dan yang akan mengarahkan pekerjaan sesuai tugas dan fungsi staf di ruangan.

\section{Kesimpulan}

Hasil penelitian ini menjelaskan bahwa fenomena yang terjadi mampu dikaji dalam penelitian ini yaitu bahwa variabel produktivitas dipengaruhi oleh beban kerja, kepemimpinan, dan motivasi secara stimultan sebesar 80,63\%, sedangkan 19,37\% dipengaruhi oleh variabel lain yang tidak diteliti dalam penelitian ini. Selain itu, dapat ditarik kesimpulan bahwa variabel produktivitas kerja perawat ruang rawat inap di Rumah Sakit Bhineka Bakti Husada Tangerang Selatan sebesar 27,9\% lebih besar dipengaruhi oleh kepemimpinan kepala ruangan dibandingkan variabel yang lain. Terdapat hubungan kualitas dan kuantitas kepemimpinan di dalam Rumah Sakit terhadap produktivitas Kerja Perawat.

\section{Saran}

Berdasarkan hasil penelitian peneliti menyarankan agar Pimpinan memberikan arahan, dukungan serta pengawasan dengan baik agar perawat merasa diakui oleh pimpinannya sehingga dapat meningkatkan motivasi kepada anggotanya yaitu perawat pelaksana ruangan agar anggotanya dapat menjalankan tugasnya dengan baik dan nyaman sehingga akan dapat meningkatkan produktivitas kerja perawat tersebut.

\section{Daftar Pustaka}

1. Undang-Undang Republik Indonesia Nomor 44 Tahun 2009 Rumah Sakit. Lembaran Negara Republik Indonesia Tahun 2009 Nomor 153; 28 Oktober 2009

2. Undang-Undang Republik Indonesia Nomor 38 Tahun 2014 Keperawatan. Lembaran Negara Republik Indonesia Tahun 2014 Nomor 307, Tambahan Lembaran Negara Republik Indonesia Tahun 2014 Nomor 5612; 17 Oktober 2014
3. Purnama, Husna. Pengaruh Gaya Kepemimpinan Terhadap Produktivitas Kerja Karyawan Bagian Bengkel pada CV Mitra Denso di Bandar Lampung. Jurnal Organisasi dan Manajemen 2 (1): 34-45; 2012

4. Supratman. Produktifitas Perawat di RS. Dr. Moewardi: Studi Komparasi Antara Metode Tim-Fungsional dan Fungsional. Jurnal Kesehatan 2 (2): 157-168; 2009

5. Yanti RI, dan Warsito BE. Hubungan Karakteristik Perawat, Motivasi, dan Supervisi dengan Kualitas Dokumentasi Proses Asuhan Keperawatan. Jurnal Managemen Keperawatan 1 (2): 107-114; 2013

6. Dharma, Surya. Manajemen Kinerja. Jakarta: Pustaka Pelajar; 2005

7. Tawale, dkk . Hubungan Antara Motivasi Kerja Perawat dengan Kecendrungan Mengalami Burnout Pada Perawat di RSUD Serui Papua. Insan 13 (2): 74 -84; 2011

8. Djiuta, Puspa. Analisa Faktor-Faktor yang Mempengaruhi Produktivitas Tenaga Kerja: Studi Kasus Industri Songket di Kecamatan Ilir Barat II dan Seberang Ulu II Kota Palembang. Jurnal Ilmiah 3 (2); 2011

9. Tanto D, Dewi SM, dan Budlo SP. FaktorFaktor yang Mempengaruhi Produktivitas Pekerja pada Pengerjaan Atap Baja di Perumahan Green Hills Malang. Jurnal Rekayasa Sipil 6 (1): 69-82; 2012

10. Irawati, Anindya. Pengaruh Beban Kerja Terhadap Produktivitas Karyawan Sentra Kredit Konsumen (SKK). Bandung . Studi. PT.Bank Negara Indonesia JPK; 2012

11. Bidang keperawatan.2014. Satuan Evaluasi Asuhan Keperawatan. Tangerang: RS.Bhineka Bakti Husada.

12. Wartana, I Made Hedy. Faktor-Faktor yang Mempengaruhi Produktivitas Kerja Karyawan pada Como Shambala Estate at Begawan Giri Ubud. Jurnal Perhotelan dan Pariwisata 1 (1): 14-34; 2011

13. Sugiyono. Metode Penelitian Kuantitatif, kualitatif dan R\&D. Bandung: Alfabeta; 2011

14. Sugiyono. Memahami Penelitian Kualitatif. Bandung: Alfabeta; 2012

15. Mustafa dan Wijaya. Panduan Tehnik Statistik SEM \& PLS dengan SPSS Amos. Yogyakarta: Cahaya Atma Pusaka; 2012

16. Alimuddin,Ibriati. Pengaruh Motivasi Terhadap Produktivitas Kerja Karyawan Pada PT. Telkom Indonesia, Tbk Cabang Makssar.Skripsi. Universitas Hasanuddin Makassar; 2012.

17. Mudayana, Ahmad A. Pengaruh Motivasi dan beban kerja terhadap kinerja karyawan dirumah sakit nur hidayah Bantul.Jurnal Kesehatan Masyarakat FKM UAD 2010.4(2): 84-9; 2010 
18. Minarsih. Hubungan Beban Kerja Perawat terhadap Kinerja Kayawan di Rumah Sakit Nur Hidayah Bantul. Jurnal Kesehatan Masyarakat FKM UAD 2010.4(2): 84-9; 2011

19. Irwadi. Penilaian Beban Kerja Perawat http://http://www.scribd.com/doc/36043707/Pen ilaian-Beban-kerja diakses tanggal 17 Februari 2015; 2007.

20. Sumarni, G. Hubungan antara efektifitas Kepemimpinan Kepala Ruangan dan Motivasi dengan Produktivitas Kerja Perawat Pelaksana di RSUP Kabupaten Tasikmalaya Jawa Barat,. Thesis, Program Magister Kesehatan Ilmu Keperawatan FIK UI Jakarta. Diunduh tanggal 9 Februari 2015; 2001

21. Widyastuti. Analisa Faktor-Faktor yang Mempengaruhi Motivasi Kerja Perawat Pelaksana Di Rumah Sakit Premier Surabaya. Skripsi Stikes Hangtua Surabaya. Diunduh tanggal 9 Februari 2015; 2014
22. Hardiansah. Hubungan Daya Kepemimpinan Kepala Ruangan Dengan Motivasi Kerja Perawat Di Rumah Sakit Umum Daerah Ambarawa. Skripsi. Stikes Hudi Waluya Ungaran. Diunduh tanggal 19 Februari 2015; 2014

23. Palangdeng. Hubungan Kepemimpinan Kepala Ruangan Menurut Persepsi Perawat Pelaksana DiRuangan Instalasi Rawat Inap RSUP Prof. Dr. R.D Kandow Manado. E journal Keperawatan Vol. 1 no. 1 Agustus 2013. Diunduh Tanggal 19 Februari 2015; 2013

24. Arta et. Al. Pengaruh Gaya Kepemimpinan Kepala Ruangan Terhadap Motivasi Kerja Perawat Dalam Melaksanakan Asuhan Keperawatan Di RSUP Sanglah Denpasar; Skripsi PSIK FK Univ. Udayana; 2012. 